\title{
Maternal Mortality and the Progressive Era: A Critical Examination of the Past to Inform the Present
}

\author{
Tamara Estes Savage \\ Department of Social Work, University of North Carolina, Pembroke, USA \\ Email: tamara.savage@uncp.edu
}

How to cite this paper: Savage, T. E. (2020). Maternal Mortality and the Progressive Era: A Critical Examination of the Past to Inform the Present. Open Journal of Social Sciences, 8, 193-206. https://doi.org/10.4236/jss.2020.84014

Received: March 20, 2020

Accepted: April 12, 2020

Published: April 15, 2020

Copyright $\odot 2020$ by author(s) and Scientific Research Publishing Inc. This work is licensed under the Creative Commons Attribution International License (CC BY 4.0).

http://creativecommons.org/licenses/by/4.0/

\begin{abstract}
More than 700 women die each year in the U.S. from pregnancy and birth related complications. This is not a new problem. Maternal mortality was a focal point for change in U.S. history during the Progressive Era. Many reforms were enacted during this historical period to decrease maternal mortality. This article critically examines the factors that contributed to the high rate of maternal mortality during the Progressive Era, as well as, efforts of the progressives to decrease the high rates of death during pregnancy and childbirth. Additionally the paper discusses contemporary maternal mortality.
\end{abstract}

\section{Keywords}

Maternal Mortality, Progressive Era Reforms, Progressive Era

\section{Introduction}

Early measurements of maternal mortality in 1900 revealed that there were 800 maternal deaths per 100,000 women (Lerberghe \& De Brouwere, 2001). These early measures were astoundingly high compared to Europe. In England and Wales in 1900, the maternal mortality rate was 400 deaths per 100,000 women. Sweden's maternal mortality rate was even lower at 200 deaths per 100,000 women (Lerberghe \& De Brouwere, 2001). Progressive reformers were distressed by the high numbers of maternal deaths especially compared to European countries. This is important to note because throughout much of U.S. history before the beginning of the $20^{\text {th }}$ century, maternal mortality was considered a natural occurrence. According to Wolf (2007), pregnancy and birth were considered risky. Yet they were an unavoidable part of life since there was no reliable form 
of birth control. Wolf (2007) states that deaths of women during childbirth were generally viewed as inescapable and the result of God's will. These deaths of women were simply deemed to be a fate that women and society had to bear. Therefore, there were no public policies or societal intervention. It was a private misery; "... one of the inexorable laws of nature" prior to the Progressive Era (Wolf, 2007: p. 135). The following is a discussion of the factors associated with maternal mortality: environmental factors, obstetrical interference, and infection. Additionally the resulting political action which ensued by the progressives is examined. Lastly the present issues in maternal mortality are explored.

The Progressive Era was a time of widespread economic, political, and societal reform. The reforms were a response to the myriad ills caused by the Industrial Revolution. The Industrial Revolution in the U.S. was a time of great change in society. The U.S. rapidly shifted from a rural, agrarian society to an urban, industrial society. According to McGerr (2003), 40\% of the wealth of the United States came from farming before the Civil War. However, by 1870 farming only contributed $16 \%$ to the wealth of the nation (McGerr, 2003). Therefore the progressive movement was composed of myriad reforms propelled by enthusiastic middle class progressives to address the ills resulting from the Industrial Revolution. These reforms were aimed at imparting the values and mores of the middle class progressives to the impoverished and the wealthy. The hope of the progressives was that the impoverished and wealthy in the U.S. would be transformed through reform which would result in a more socially just, moral America (McGerr, 2003).

The U.S. Children's Bureau was a federal bureau formed in 1912 in response to staggering levels of infant mortality. In 1911 the U.S. infant mortality rate was 135 deaths per 1000. In a ranking of 30 countries according to rates of infant mortality, the U.S. was ranked $18^{\text {th }}$ (Brosco, 1999). The U.S. Children's Bureau embarked on a large scale public health campaign which focused on improving the care of infants (Engs, 2005).

The public health campaign consisted of programs such as the national Better Babies Week which urged mothers to take their babies to the doctor to have them weighed and measured (Engs, 2005). The U.S. Children's Bureau also distributed posters urging mothers to breastfeed and pamphlets explaining infant hygiene, safe milk storage, and infant safety (Wolf, 2007). As reformers delved deeper into the issue of infant mortality, they realized that many women were dying in childbirth. Furthermore, those healthy children born to a mother who died in childbirth had an increased chance of dying soon after birth due to malnutrition and sometimes neglect (Wolf, 2007). Therefore, maternal mortality became a public health issue in attempts to decrease infant mortality (Perry \& Smith, 2006).

Once recognized as an issued that needed to be addressed, a debate ensued regarding the causation of the high rates of deaths ensued. Many progressive reformers maintained that the problem was environmental. Many physicians including the burgeoning specialty of obstetrics maintained that midwifery was to 
blame. In addition there were some who believed that germs were the reason that women were dying. It was a debate that raged until the mid-1930's when maternal deaths in the United States began to decline (Loudon, 2000).

\section{Description and Analysis}

\subsection{Environmental Factors}

Pregnant women living in the cities during the Progressive Era were subjected to a plethora of adverse environmental factors. Cities did not provide the basic necessities for healthy living to the masses of people working in the factories and mills. The living conditions were deplorable with little sanitation, clean water, ventilation, or heat in the winter (Addams, 1895; Kelley, 1895; McGerr, 2003). As Kelley (1895) observed, people lived in congested tenement houses with "... no fire-escapes, and no sufficient water supply, the danger of death by fire ...” (p. 36). Kelley (1895) described the vermin which infested the tenements. She also stated that families had to endure the fumes of the charcoal heaters and gasoline stoves without proper ventilation in the winter in order to escape freezing to death (Kelley, 1895).

In addition to the appalling living conditions in which pregnant women and their families lived, impoverished pregnant women worked in the factories, mills, and at home. They worked long hours six to seven days a week in dangerous working conditions whether working away from home or in the home. Workers in the garment district, jobs that were heavily populated by women, were subjected to poisonous dyes, dangerous inhalants such as tiny fibers, and dangerous machinery without any protective equipment (Kelley, 1895). Women who worked at home for the sweating system were the least protected because they worked for an illicit business that had no regard for their health and safety. There were many other men and women to fill a vacancy due to illness or death. Therefore, sweaters including pregnant women worked to the point of exhaustion. They made custom, upscale apparel for the wealthy at foot-peddled sewing machines until collapse. Women also sewed buttons by the hundreds in order to avert starvation for their families (Kelley, 1895).

Acquiring basic nutrition was a challenge for the poor during the $19^{\text {th }}$ and early $20^{\text {th }}$ century. The traditional means of growing and storing food grown locally changed with industrialization. The migration of large groups of people to urban centers meant that food had to be brought to the cities from outside sources. The rural poor working as sharecroppers and tenet farmers were often not allowed to grow their own food or did not have the time and resources (Piott, 2011). Instead they bought most of their food and supplies from the local country store to which they often mortgaged their crops for credit for food, basic supplies, and farming needs (Piott, 2011). Therefore, people no longer had control over the growing and procurement of their own food. The result was adulterated milk, spoiled meat, few fresh fruits and vegetables, and medicines laced with cocaine and opium (Law \& Libecap, 2006). Pregnant women were exposed 
to these noxious substances which led to malnutrition and sickness. Malnutrition and sickness from tainted food compromised the physical strength needed to maintain pregnancy and survive labor for many women.

In addition to decreased physical strength, malnutrition often resulted in rickets and pellagra. Rickets is the weakening of bones because of a lack of vitamin D (Engs, 2003). Vitamin D can be obtained from dairy products and sunlight. However, much of the milk available was tainted with chalk and water. The milk contained little nutritional value and often led to diarrhea and death in infants (Wolf, 2007). Furthermore, much of the urban poor were not frequently exposed to sunlight. Many worked in dank, dark factories and mills, and lived in dank, dark tenement houses.

Rickets was especially detrimental to women of childbearing age as the vitamin deficiency often led to the deformation of the pelvis (Arms, 1996). A deformed pelvis could obstruct the birth canal. An obstruction of the birth canal often resulted in death of the mother and the death of the baby since cesarean sections were rarely performed before the beginning of the profession of obstetrics (Arms, 1996).

Pellagra is also a diet related disease which afflicted the poor before and during the Progressive Era. Pellagra is caused by a vitamin B 3 deficiency in populations that consume mostly corn products (Marks, 2003). The vitamin deficiency was debilitating and deadly. In the rural south, pellagra was of epidemic proportions (Marks, 2003). Both black and white women were the primary casualties of pellagra, including pregnant women.

Given all the information concerning the importance of environmental factors in the health outcomes for pregnant women, there is still a debate as to how nutrition was related to maternal mortality. Loudon (2000) argues that impoverished conditions including malnutrition were a minor contributor to maternal mortality. He concedes that starvation which did occur in some circumstances would have certainly contributed to maternal deaths. He maintains that between 1900 and 1935 many progressive reforms which were not medical reforms such as better housing, sanitation, clean water, nutrition, and personal hygiene were enacted (Loudon, 2000). Therefore, he argues that maternal mortality should have decreased if these factors were in fact culprits in the women's deaths. However the maternal mortality rate did not begin to decrease until the mid-1930's (Lerberghe \& De Brouwere, 2001). Therefore he posits that more salient reasons for the high rates of deaths involved the standard of obstetric care the women received and the prevalence of pathogenic bacteria (Loudon, 2000).

\subsection{Obstetrical Interference}

Obstetrics was a burgeoning field at the turn of the $20^{\text {th }}$ century. Midwives had been the standard of care for centuries. Obstetricians argued that the high maternal mortality rate first measured in 1900 as 800 maternal deaths per 100,000 women was the result of poor care given by midwives during labor (Lerberghe $\&$ 
De Brouwere, 2001). Obstetricians argued that midwives were not properly trained. They also contended that since most midwives were African American or immigrants they were genetically inferior (Dawley, 2002; Devitt, 1979). Therefore the argument was that since they were women and often women of color, they could never be relied upon to provide adequate maternal care. However, statistical measurements at the time did not support these claims.

A study was conducted in New York City in 1913 (Devitt, 1979). At the time, midwives attended $40 \%$ of all births and physicians attended $60 \%$ of all births. The study concluded that the midwives had better birth outcomes than physicians based on the rate of death from puerperal sepsis, death from Streptococcus pyogenes infection. The death rate of women from puerperal sepsis attended by midwives in 1913 was $22 \%$. However the rate of death for women attended by physicians was 69\% (Devitt, 1979).

Another study examining maternal deaths in Newark, New Jersey from 1916 to 1921 also supported the efficacy of midwives. In this study midwives attended 30,945 births, and 47 women died (Levy, 1918). In the same study, physicians attended 38,706 live births, and 267 women died (Levy, 1918). The Children's Bureau also explored maternal mortality. They looked at maternal deaths in Philadelphia from 1914 to 1930 . The researchers found that midwives attended 90,925 births with 77 maternal deaths. Physicians attended 593,861 deaths with 4428 maternal deaths (Devitt, 1979).

Even given this strong evidence of the efficacy of midwives compared to physicians, births attended by midwives dropped from 50\% in 1900 to $15 \%$ in 1930 (Dawley, 2002). Obstetricians effectively marginalized the service of midwives. They convinced the public and medical community that midwives were not capable of delivering women and babies safely through labor. The 1920's saw the ascendency of the obstetrical profession to the detriment of pregnant women. During this time the rate of maternal mortality rose to over 900 deaths per 10,000 women (Lerberghe \& De Brouwere, 2001). Those who were attended by midwives in their homes for their birth were the safest (Loudon, 2000). Those who were attended by obstetricians in the hospital were in the most danger of death. Therefore, the death rate was the highest in populations of wealthy women.

Wealthy women died at a higher rate than poor women because obstetricians employed dangerous "medical” techniques during women's labor. First, obstetricians used anesthesia. Obstetricians viewed birth as "pathologic" requiring medical intervention (DeLee, 1915: p. 116). The new profession of obstetrics maintained that they had special expertise to address the disease of labor. This special expertise was in the form of new scientific methods of delivering infants and standardizing the care of laboring women. They purported that all of this was to be done in the strictly controlled environment of the hospital (DeLee, 1915). As part of their intervention protocol, obstetricians anesthetized laboring women in efforts to assert control over the labor process. Women were anesthetized to the point that they were not aware of the birthing process and could no 
longer push the baby through the birth canal (Wolf, 2007).

Second, obstetricians began to commonly use forceps. Leading obstetricians such as DeLee (1915) urged the routine use of forceps to intervene during labor and wrote that forceps were a technological advance in obstetrical science. Forceps had to be used when women were heavily anesthetized. During normally progressing labor, the uterus contracts and the woman eventually pushes the infant through the birth canal. However, obstetricians gave laboring women large doses of anesthetizing drugs, so the women were not cognizant of the urge to push. Since the women could not expulse their babies naturally, obstetricians used forceps to forcibly remove the infant from the birth canal (Wolf, 2007). If forceps did not work, obstetricians pulled the infant out with their bare hands (Arms, 1996). The result was sometimes death of the baby from the extraction force and/or trauma from the forceps (Arms, 1996). Women also suffered tissue damage and sometimes died of hemorrhaging (Wolf, 2007).

Third, obstetricians intervened in various other ways which had no medical basis but provided a standard of routine care that all obstetricians were urged to follow. For example, they required that the pubic area of women's genitalia be shaved (Arms, 1996). They also routinely performed episiotomies, cutting the perineum to allow more space for the baby's head, regardless if needed (Wertz, 1980). Most of these interventions were needless and risky procedures. However, it was the consequence of these interferences that was most fatal, infection.

\subsection{Infection}

Infection was a significant cause of death for women during the Progressive Era in general. According to Taylor (1921), 40\% to 50\% of maternal deaths were due to infection. These deaths were most often attributed to puerperal fever. Puerperal fever was caused by the bacterium, Streptococcus pyogenes (Loudon, 2000). This bacterium was extremely virulent and spread throughout the body rapidly leading to sepsis. Even though germ theory was well known by the turn of the $20^{\text {th }}$ century, obstetricians often transmitted the pathogenic bacteria to laboring women through several routes (Perry \& Smith, 2006). First, many obstetricians did not wash their hands between patients or wear gloves that were available (King, 1996). De Costa (2002) quotes Charles Meigs', a 19 ${ }^{\text {th }}$ century obstetrician, response to the urging that doctors wash their hands. He stated, "Doctors are gentlemen, and gentlemen's hands are clean" (as cited in De Costa, 2002: p. 669).

Second, since obstetricians believed in intervening in all births, they repeatedly checked the progress of labor by inserting their hands into the vaginal canal (Arms, 1996). They also enforced pubic area shaving which resulted in tiny nicks. These nicks provided opportune conditions for bacteria to thrive. Lastly, episiotomies and use of forceps tore genital tissue which resulted in lesions. Lesions in the genital area are also an ideal environment for the replication of bacteria such as Streptococcus pyogenes (Loudon, 2000). 


\subsection{Decline in Maternal Mortality}

\section{Scientific innovation and obstetrical changes.}

Maternal mortality began to sharply decline in the U.S. in the mid-1930's. In 1935 the maternal mortality rate was 600 deaths per 100,000 births which was a drastic decrease form the 900 deaths per 100,000 births in 1920 (Loudon, 2000). The maternal mortality rate continued to decline over the next two decades. By 1950 , the maternal mortality rate was at its lowest rate ever recorded, 100 deaths per 100,000 births (Loudon, 2000). From 1900 to 1950 there was a nine fold reduction in maternal mortality in the U.S. (Loudon, 2000). How did this happen?

At the beginning of the 1930's there was a confluence of scientific innovations and improvements in obstetrical care. The scientific innovation of primary importance to decreasing maternal mortality was the discovery of sulfonamides (De Costa, 2002; Loudon, 2000). Sulfonamides were extraordinarily effective at killing Streptococcus pyogenes. Therefore the rate of maternal death from puerperal fever plummeted. Penicillin was also discovered which aided in killing many strains of bacteria that were not affected by sulfonamides which attributed to maternal illness and death (De Costa, 2002).

For the first time maternal hemorrhaging was addressed with new technology and drugs. Obstetricians began to use the new scientific advance, blood transfusions (Loudon, 2000). If the hemorrhaging could be stopped, mothers had another chance of survival through blood transfusions. To assist in abating hemorrhaging, obstetricians had a new drug, ergometrine. Ergometrine was given to decrease maternal bleeding and expedite the delivery of the placenta (Net Doctor, 2011).

Obstetricians also improved their standard of care. They began to fully understand the necessity to wash their hands and use gloves as barriers to infection (De Costa, 2002). Obstetricians also learned better anesthesia techniques (Arms, 1996; Loudon, 2000). Since women were more awake, they could push the infant out of the birth canal themselves during normal births. This led to a decrease in the use of forceps during delivery. In addition, obstetricians interfered less in births that were progressing normally (Loudon, 2000). They abandoned the philosophy that there was one standard of care for all mothers. Instead as a profession they reserved many of their specialist techniques for births that were not progressing normally. Lastly, obstetrics' effective elimination of midwives left a gap in service delivery for much of the populous. To fill this gap, more doctors were trained in the specialty of obstetrics. The profession grew and more and more women were served by both charitable groups of obstetricians and private pay obstetricians (Devitt, 1979; Loudon, 2000).

Improved Environmental Factors.

According to Perry and Smith (2006), the improvement of environmental factors resulted in fewer deaths including maternal deaths. Because of the plethora of progressive reforms in urban areas, sewage systems and water filtration systems were built. Garbage disposal was implemented and dilapidated tenement 
houses were refurbished (Perry \& Smith, 2006). In addition The Pure Food and Drugs Act was passed in 1906. This federal legislation was an attempt of the government to regulate interstate trade of food and drugs (Law \& Libecap, 2006). The intent was that the regulation of interstate trade of food and drugs would decrease the sale of adulterated food and poisonous drugs to consumers (Law \& Libecap, 2006). The act was eventually successful in reducing the egregious adulteration of the food and drugs in the U.S.

\section{Maternal health policy initiative.}

For the first time in U.S. history, policy was enacted on behalf of women's health, the Sheppard-Towner Act of 1921. The early work of progressive reformers led to the initial recognition of maternal mortality through the work of the U.S. Children's Bureau. This work led to many mother and infant educational programs, prenatal care for pregnant women, and better obstetrical care. All of this hard work of the progressives resulted in a landmark policy.

The Sheppard-Towner Act of 1921 was the first social security legislation in the U.S. The purpose of the federal act was to provide funds for the healthcare of all women while pregnant (McDonagh, 2009). In 1921 when the act was implemented the maternal mortality rate was at its highest level ever recorded in the U.S. (Loudon, 2000). In addition, the $19^{\text {th }}$ amendment had been ratified, and women had the right to vote. Therefore, the progressive reformers saw that the time had finally come for pregnant women to be recognized as a vulnerable population in need of services (McDonagh, 2009). Not everyone agreed with the progressives.

Many including the American Medical Association (AMA) were outraged by the Sheppard-Towner Act. The AMA stated that the act was, “... hostile and contradictory to the liberal tradition of the American state" (McDonagh, 2009: p. 194). In addition, the legislation was seen by many as socialist and communist. It was referred to as a "Bolshevik conspiracy" by its opponents (McDonagh, 2009: p. 194).

However, the reality was that the Sheppard-Towner Act led to 3000 maternal health centers which provided healthcare and services to pregnant women (McDonagh, 2009). In the years that the act was in effect, the maternal mortality rate dropped in the service areas. In 1928 Congress did not renew the act (McDonagh, 2009). The principle opponent to the act was the AMA (McDonagh, 2009). Since the Sheppard-Towner Act there have been some social welfare programs to assist impoverished pregnant women with nutrition and healthcare. These programs are only available to the most in need. There is no universal healthcare for pregnant women in the U.S. at present. In addition to sparse services, maternal mortality seems to be increasing after years of stabilization.

\section{Contemporary Maternal Mortality}

Maternal Mortality stabilized during the 1960 's to 6.6 maternal deaths per 
100,000 births (Lerberghe \& Brouwere, 2001; U.S. Department of Health and Human Services, 2011). However in the early part of the $21^{\text {st }}$ century the maternal mortality rate began to rise. Today maternal mortality is on the rise. After examining the efforts made to decrease the maternal death rate during the Progressive Era, it is evident that some of the problems that were addressed by the progressives are still present. First as in the years before the Sheppard-Towner Act, many women do not have access to healthcare. Twelve percent of women of reproductive age do not have health insurance in the U.S. (Guttmacher Institute, 2018). Furthermore, $15 \%$ of women do not receive sufficient prenatal care (Osterman \& Martin, 2018).

Second, in addition to lack of care before birth, women in the U.S. are increasingly subjected to obstetrical interventions such as cesarean sections which are associated with increased maternal mortality (Singh, 2010). Cesarean sections which account for $32 \%$ of all deliveries (Centers for Disease Control \& Prevention [CDC], 2017). This percentage is more than double the percentage that the World Health Organization suggests (Amnesty International, 2011). Furthermore, provider errors can also contribute to mortality. For example, a review conducted by the CDC Foundation (2018) of 237 maternal deaths in nine states concluded that most of deaths in the study were attributed to preventable clinician errors. Such errors included lack of a complete assessment which led to misdiagnosis of complications and delayed or ineffective response to complications (CDC Foundation, 2018). In addition, lack of communication and patient care coordination among healthcare providers was also cited (CDC Foundation, 2018).

Third, although pellagra and rickets are no longer dietary issues, obesity is. Obesity, a form of malnutrition just as pellagra and rickets were during the Progressive Era. Obesity can lead to hypertension and diabetes which are both risk factors for complications during pregnancy and birth (CDC, 2017). Lastly, infection and hemorrhaging still account for a significant percentage of maternal deaths. According to the CDC (2017), infection accounted for $12.8 \%$ of the maternal deaths from 2011 to 2014. Additionally, 11.5\% of maternal deaths occurred because of hemorrhage during this same time period (CDC, 2017).

\section{Implications}

There are several implications of viewing maternal mortality through an historical lens. The U. S. has experienced great strides in reducing maternal mortality since the Progressive Era. Much of these strides occurred in part because of the change in society's conceptualization of the issue which led to policy changes. However, maternal mortality began to increase in the 1990's and is continuing to increase. Thus there are three recommendations resulting from this critical examination of the historical context. First, this is an opportunity to conduct research to determine what is causing the increase in maternal mortality after many decades of stabilization of death rates. Second, this is a social justice issue. 
Women in the U.S. are dying preventable deaths. Every woman should have the right to have a safe birth and a safe delivery. Scholars could work with organizations that serve vulnerable populations of pregnant women to help increase their service provision. Scholars could partner with communities to implement innovative interventions that target pregnant women. Third, this is a policy issue. There are policies in place which make it difficult for poor women to obtain the resources that they need to facilitate a healthy pregnancy. These policies need to be amended or discarded. This is the moment for scholars concerned with this issue to be involved at the policy level in ensuring that all women have the medical care they need to survive labor.

\section{Conclusion}

This paper critically examines maternal mortality during the Progressive Era. Maternal mortality evolved from a fate that some women and families had to accept to a problem that deserved the attention of society during the Progressive Era (McGerr, 2003). Due to the combination of many reforms and innovations during the Progressive Era, the maternal mortality rated began to decrease. Today maternal mortality is on the rise (London, 2000). After examining the efforts made to decrease the maternal death rate during the Progressive Era, it is evident that some of the problems that were addressed by the progressives are still present. Thus, as the medical and public health communities look forward to find solutions to decrease maternal mortality in the U.S., it is important to examine the historical context of efforts to solve the problem. The Progressive Era is a productive place to begin as it is the first time in U.S. history that maternal mortality was defined as a societal problem worth study and governmental action.

Due to the combination of many reforms and innovations, the maternal mortality rated began to decrease. The plethora of environmental reforms led to the Pure Food and Drugs Act of 1906 which decreased the adulteration of food and drugs (Law \& Libecap, 2006). All women were offered maternal health care for almost a decade because of the Sheppard-Towner Act of 1921 (McDonagh, 2009). In addition, sulfonamides and antibiotics led to increased survival from infections. Blood transfusions, ergometrine, and decreased obstetrical interference during labors also led to a marked decrease in maternal mortality (Loudon, 2000). This decrease stabilized in the 1960's and remained low until 2007.

In 2007 the maternal mortality rate was double the maternal mortality rate two decades earlier (Amnesty International, 2011). It has continued to increase. According to Amnesty International (2019) two to three women die each day in the U.S. from pregnancy and birth related reasons. Furthermore, Amnesty International (2019) states, "Although the United States spends $\$ 98$ billion a year on health care (more than any other country), women in the US actually have a greater risk of dying from pregnancy-related complications than women in 49 countries." Many pregnant women do not receive sufficient prenatal and mater- 
nal care (Amnesty International, 2019). Also African Americans women have less access to prenatal care and health insurance than white women (Chalhoub \& Rimar, 2018). Thus as the social work, public health, and medical communities look forward to find solutions to decrease maternal mortality in the U.S., it is important to examine the historical context of efforts to solve the problem. The Progressive Era is a productive place to begin as it is the first time in U.S. history that maternal mortality was defined as a societal problem worth study and governmental action.

This paper critically examines maternal mortality during the Progressive Era. Maternal mortality evolved from a fate that some women and families had to accept to a problem that deserved the attention of society (Perry \& Smith, 2006). Progressive reformers recognized the problem and began to measure it using scientific methods (McGerr, 2003). Once measured progressive reformers realized that the death of mothers was resulting in the death of infants born to dying mothers. Infant mortality was documented early and a main reform effort for the progressives. Therefore, maternal mortality was taken up by the infant mortality movement and efforts began to mitigate the death of women in childbirth.

To mitigate maternal mortality, progressives first needed to determine the causation of the deaths. Many reasons for the deaths were examined and there was some disagreement. The prevailing theory of many progressives was that mothers died because they lived in the squalor of the tenements of the north and the desolation of the sharecropping farms and tenet farms of the south. The environmental conditions of they lived in were unsuitable to adequate maternal health. The belief was that women died in childbirth because they worked to exhaustion in factories, mills, farms, and homes (Perry \& Smith, 2006). Women were exposed to sewage, toxic chemicals, and noxious fumes. They lived in tenements without proper ventilation, heating, or cooling. Women did not have clean water to drink and the medicines that they were prescribed were adulterated with narcotics and opiates (Law \& Libecap, 2006). In addition they were sometimes malnourished because their food was pumped with preservatives and their milk was watered down and filled with chalk (Wolf, 2007). Pregnant women rarely had access to fresh fruits and vegetables. They simply were not available to poor women in the cities. Rural poor women did not have the time, space, or resources to grow enough food to stay properly nourished (Piott. 2011). Therefore, pregnant women were exposed to an excess of dangerous environmental factors and malnutrition before and during their pregnancy. When it was time to deliver their infants, many pregnant women were not physically able to survive the task.

The second prevailing theory was that the standard of obstetrical care was inadequate. Women were dying in exorbitant numbers at the hands of obstetricians. Obstetricians had the worst rates of maternal mortality in most studies when compared to midwives (Loudon, 2000). Yet, they waged a campaign to discredit midwifery. Midwives were mostly African American and immigrants. 
The obstetricians argued that midwives were dangerous, unclean, and genetically inferior because they were women of color (Dawley, 2002; Devitt, 1979). The obstetricians were successful. The practice of midwifery drastically decreased in the U.S. However, the maternal mortality rate continued to rise.

No one was injured more from the prevailing popularity of obstetricians than wealthy women (Loudon, 2000). Wealthy women wanted safe births, and they were convinced that obstetricians were the best care providers. Obstetricians experimented on the wealthy women. They tested new obstetrical techniques using anesthesia, forceps, and unsanitary practices. They cut the women and shaved them (DeLee, 1915). Much of what they did had no sound medical basis. Obstetricians interfered in all births regardless if they were normally progressing births. They were attempting to legitimize their profession and set rigid standards of care. The women died.

The third theory of maternal mortality is infection. It was estimated that approximately half of maternal deaths during the Progressive Era probably occurred due to puerperal fever (Taylor 1921). Puerperal fever was a bacterial infection that thrived in hospitals because of the unsanitary birthing conditions. The result was sepsis and death. However, during the mid-1930's the discovery of sulfonamides and antibiotics brought an end to puerperal fever in the U.S. (De Costa, 2002; Loudon, 2000). Women also benefited from other medical innovations.

Many women died from hemorrhaging because of the interference of obstetricians in the birth process. A new drug, ergometrine, was discovered which decreased hemorrhaging (Net Doc, 2011). This new drug was coupled with the new technology, blood transfusions, which increased the chances of survival of many women (Loudon, 2000). Other changes occurred within the specialty of obstetrics. Obstetricians trained more doctors and served more women. The profession also began to focus less on interference during normal births and more on intervening during difficult births (Arms, 1996, Loudon, 2000).

\section{Conflicts of Interest}

The author declares no conflicts of interest regarding the publication of this paper.

\section{References}

Addams, J. (1895). The Settlement as a Factor in the Labor Movement. In R. C. Wade (Ed.), Hull-House Maps and Papers: Residents of Hull-House (pp. 183-204). Berlin: Springer.

Amnesty International (2011). USA Urged to Confront Shocking Maternal Mortality Rate.

http://www.amnesty.org/en/news-and-updates/usa-urged-confront-shocking-maternal -mortality-rate-2010-03-12

Amnesty International (2019). Lobby for Maternal Health in the US.

https://www.amnestyusa.org/lobby-for-maternal-health-in-the-us/ 
Arms, S. (1996). Immaculate Deception 11: Myth, Magic and Birth. Berkeley, CA: Celestial Arts.

Brosco, J. P. (1999). The Early History of the Infant Mortality Rate in America: A Reflection upon the Past and a Prophecy of the Future. Pediatrics, 103, 478-485.

https://doi.org/10.1542/peds.103.2.478

Chalhoub, T., \& Rimar, K. (2018). The Health Care System and Racial Disparities in Maternal Mortality.

https://www.americanprogress.org/issues/women/reports/2018/05/10/450577/health-ca re-system-racial-disparities-maternal-mortality/

Dawley, K. (2002). Perspectives on the Past, View of the Present: Relationship between Nurse-Midwifery and Nursing in the United States. The Nursing Clinics of North America, 37, 747-755. https://doi.org/10.1016/S0029-6465(02)00026-9

De Costa, C. M. (2002). The Contagiousness of Childbed Fever: A Short History of Puerperal Sepsis and Its Treatment. The Medical Journal of Australia, 177, 668-671. https://doi.org/10.5694/j.1326-5377.2002.tb05004.x

DeLee, J. B. (1915). Progress toward Ideal Obstetrics. Transactions of the American Association for the Study and Prevention of Infant Mortality, 6, 114-138.

Devitt, N. (1979). The Statistical Case for Elimination of the Midwife: Fact versus Prejudice, 1890-1935. Women \& Health, 4, 169-186. https://doi.org/10.1300/J013v04n02 06

Engs, R. C. (2003). The Progressive Era's Health Reform Movement: A Historical Dictionary. West Point, CT: Praeger.

http://books.google.com/books?id=mNeGQRBgd MC\&pg=PA3\&lpg=PA3\&dq=ricket

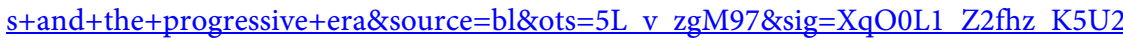
$\underline{\text { s1UrBQtxMA\&hl=en\&ei }=\mathrm{kd} 3 \mathrm{TTVTqH}} \mathrm{H}$ KKsgK8ofy6Dg\&sa=X\&oi=book result\&ct=re sult\&resnum $=2 \& v e d=0 \mathrm{CCQQ6AEwAQ} \# \mathrm{v}=$ onepage $\& \mathrm{q}=$ =rickets $\% 20$ and $\% 20$ the $\% 20$ pro gressive $\% 20 \mathrm{era} \& \mathrm{f}=$ false

Engs, R. C. (2005). The Eugenics Movement: An Encyclopaedia. Westport, CT: Greenwood Press. http://www.indiana.edu/ engs/ebook/samples.html

Kelley, F. (1895). The Sweating System. In R. C. Wade (Ed.), Hull-House Maps and Papers: Residents of Hull-House (pp. 27-45). Berlin: Springer.

King, C. R. (1996). The New York Maternal Mortality Study: A Conflict of Professionalization. In P. K. Wilson, A. Dally, \& C. R. King (Eds.), Childbirth: Changing Ideas of Practice in Britain and America 1600 to the Present (pp. 110-136). Berlin: Springer.

Law, M., \& Libecap, G. D. (2006). The Determinants of Progressive Era Reform: The Pure Food and Drugs Act of 1906 (pp. 319-342). National Bureau of Economic Research. http://www.nber.org/books/glae06-1

Lerberghe, W. V., \& De Brouwere, V. (2001). Of Blind Alleys and Things that Have Worked: History's Lessons on Reducing Maternal Mortality. Studies in Health Services Organization \& Policy, 17, 1-26.

Levy, J. (1918). The Maternal and Infant Mortality in Midwifery Practice in Newark, New Jersey. In E. G. Zinke (Ed.), Transactions of the American Association of Obstetricians and Gynecologists (Vol. 30, pp. 208-227). Berlin: Springer.

https://books.google.com/books?hl=en\&lr=\&id=crECAAAAYAAJ\&oi=fnd\&pg=PA208 $\& \mathrm{dq}=$ levy+the+maternal+and+infant + mortality + in + midwifery + practice $\&$ ots $=1 L O S 00$ $\underline{\mathrm{m} 3 \mathrm{t} 9 \& \mathrm{sig}=\text { YAAkNlLOPHWNw PPGPFrYKt6qg\#v }=\text { onepage } \& \mathrm{q}=\text { levy\%20the } \% 20 \mathrm{mat}}$ ernal\%20and\%20infant\%20mortality\%20in $\% 20$ midwifery\%20practice $\& \mathrm{f}=$ false

Loudon, I. (2000). Maternal Mortality in the Past and Its Relevance to Developing Countries Today. American Journal for Clinical Nutrition, 72, 241S-246S. 
https://doi.org/10.1093/ajen/72.1.241S

Marks, H. M. (2003). Epidemiologist Explain Pellagra: Gender, Race, and Political Economy in the Work of Edgar Sydenstricker (Vol. 58, pp. 34-55). Oxford: The Oxford University Press. https://doi.org/10.1093/jhmas/58.1.34

McDonagh, E. L. (2009). The Motherless State: Women's Political Leadership and American Democracy. Chicago, IL: The University of Chicago Press. http://books.google.com/books?isbn= https://doi.org/10.7208/chicago/9780226514567.001.0001

McGerr, M. (2003). A Fierce Discontent: The Rise and Fall of the Progressive Movement in America, 1870-1920. New York: Free Press.

Net Doctor (2011). Ergometrine. http://www.netdoctor.co.uk/medicines/100000947.html

Perry, E. I., \& Smith, K. M. (2006). The Gilded Age and Progressive Era: A Student Companion. New York: Oxford University Press, Inc.

Piott, S. L. (2011). Daily Life in the Progressive Era. http://books.google.com/books?id=psVDZPcFF2YC\&pg=PA189\&lpg=PA189\&dq=rick ets + and + the + progressive+era\&source $=$ bl\&ots $=$ Ty $I 23 y s G c \& s i g=2 \mathrm{tHt} 3 \mathrm{gMYeHakO} 6 \mathrm{hF}$ MuakG9JsKNM\&hl=en\&ei=kd3TTvTqHcKKsgK8ofy6Dg\&sa=X\&oi=book result\&ct= re-

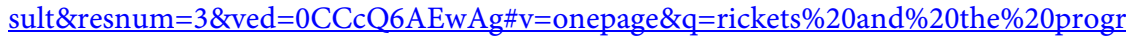
essive $\% 20$ era $\& \mathrm{f}=$ false

Taylor (1921). Prenatal and Obstetric Care. The Pennsylvania Medical Journal, 25, 39-41.

U.S. Department of Health and Human Services, Health Resources and Services Administration, Maternal and Child Health Bureau (2011). Child Health. http://mchb.hrsa.gov/chusa11/hstat/hsi/pages/208mm.html

Wertz, D. C. (1980). Man-Wifery and the Rise of Technology: The Problem and Proposals for Resolution. In H. B. Holmes, B. B. Hoskins, \& M. Gross (Eds.), Birth Control and Controlling Birth: Women-Centered Perspectives (pp. 147-162). Berlin: Springer. http://books.google.com/books?id=HRY3PNeW6KYC\&pg=PA161\&lpg=PA161\&dq=e pisioto-

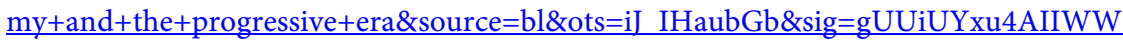
XMfrA8lkS 460\&hl=en\&ei=1XnXTpKNF8eq https://doi.org/10.1007/978-1-4612-6005-9 21

Wolf, J. H. (2007). Saving Babies and Mothers: Pioneering Efforts to Decrease Infant and Maternal Mortality. In J. W. Ward, \& C. Warren (Eds.), Silent Victories: The History and Practice of Public Health in Twentieth-Century America. Oxford: Oxford University Press.

http://books.google.com/books?id=5SDkvRBkQXAC\&pg=PA135\&lpg=PA135\&dq=ma ter-

$\underline{\text { nal }+ \text { mortality }+ \text { and }+ \text { the }+ \text { progressive }+ \text { era } \& \text { source }=\text { bl } \& \text { ots }=\text { sh } 5 \text { CDPoqaM } \& \text { sig }=1 \mathrm{cIa} 0 \mathrm{Ps}}$ FqQCp5HpA8SCA9XZunMo\&hl=en\&ei=Bzu7TuOdD5PegQeq9sTICA\&sa=X\&oi=bo ok result \&ct $=$ result\&resnum $=4 \& v e d=0 C C s Q 6 A E w A w \# v=$ onepage $\& q=$ maternal $\% 20 \mathrm{~m}$ ortality\%20and\%20the\%20progressive $\% 20$ era\&f=false https://doi.org/10.1093/acprof:oso/9780195150698.003.07 